\title{
Correction to: Seagrasses-a Tribute to Dr. Susan Williams
}

\author{
Robert J. Orth ${ }^{1}$. Ken L. Heck ${ }^{2}$
}

Published online: 16 January 2021

(C) Coastal and Estuarine Research Federation 2021

\section{Correction to: Estuaries and Coasts https://doi.org/10.1007/s12237-020-00885-z}

In the original version of this article the incorrect corresponding author was indicated. The original article has been corrected.

The online version of the original article can be found at https://doi.org/ 10.1007/s12237-020-00885-Z

\section{Robert J. Orth}

jjorth@vims.edu

1 Virginia Institute of Marine Science, College of William and Mary, Gloucester Point, VA 23062, USA

2 Dauphin Island Sea Lab, University of Alabama, Dauphin Island, AL 36528, USA 